\title{
Antidepressant Activity of Spirulina Platensis in Models of Depression
}

\section{Stephen D Persell*, Mark W Friedberg, Daniella Meeker}

Department of Psychological Medicine, UK.

*Corresponding Author : Stephen D Persell, Department of Psychology, UK. E-mail: spersll@nmff.org

Received date: May 03, 2017;Accepted date : May 16, 2017; Published date: May $29,2017$.

Citation for this Article: Stephen D Persell, Antidepressant activity of spirulina platensis in models of depression. J Psychology and Mental Health Care . Doi: 10.31579/2637-8892/003

Copyright : (c) 2017 Stephen D Persell. This is an open-access article distributed under the terms of The Creative Commons Attribution License, which permits unrestricted use, distribution, and reproduction in any medium, provided the original author and source are credited.

\section{Abstract}

Depression is the most common of the affective disorders (disorders of mood rather than disturbances of thought or cognition); it may range from a very mild condition, bordering on normality, to severe (psychotic) depression accompanied by hallucinations and delusions. Worldwide, depression is a major cause of disability and premature death. Unipolar depression is commonly (about $75 \%$ of cases) non-familial, clearly associated with stressful life-events and accompanied by symptoms of anxiety and agitation; this type is sometimes termed reactive depression. Other patients (about 25\%, sometimes termed endogenous depression) show a familial pattern, unrelated to external stresses, and with a somewhat different symptomatology. This distinction is made clinically, but there is little evidence that antidepressant drugs show significant selectivity between these conditions.

\section{Introduction}

The symptoms of depression include emotional and biological components:

\section{- Emotional symptoms:}

1. misery, apathy and pessimism

2. low self-esteem: feelings of guilt, inadequacy and ugliness

3. indecisiveness, loss of motivation.

\section{- Biological symptoms:}

1. retardation of thought and action

2. loss of libido

3. sleep disturbance and loss of appetite.

There are two distinct types of depressive syndrome, namely unipolar depression, in which the mood swings are always in the same direction, and bipolar affective disorder, in which depression alternates with mania. Mania is in most respects exactly the opposite, with excessive exuberance, enthusiasm and self-confidence, accompanied by impulsive actions, these signs often being combined with irritability, impatience and aggression, and sometimes with grandiose delusions of the Napoleonic kind. As with depression, the mood and actions are inappropriate to the circumstances.

Bipolar depression, which usually appears in early adult life, is less common and results in oscillating depression and mania over a period of a few weeks. There is a strong hereditary tendency, but no specific gene or genes have been identified either by genetic linkage studies of affected families, or by comparison of affected and non-affected individuals.

Methods

- To study the effect of SP on behavior models of depression like forced swim test, tail suspension test.

- To study the effect of $S P$ on mechanism based models of depression like 5-HTP induced head twitches, clonidine induced aggression and L-Dopa induced hyperactivity and aggressive behavior.

- To study the effect of $S P$ on anti-oxidant levels of brain.

\section{Objective Of The Study}

Spirulina platensis $(S P)$ is a type of fresh-water blue-green algae which grows naturally in warm climate countries and has been considered as supplement in human and animal food (Ruiz Flores et al., 2003). The numerous toxicological studies have established its safety for human consumption (Hirahashi et al., 2002). SP has anti-oxidant property as it contains Carotenoids and also rich in amino acids like Tryptophan, Phenylalanine, Tyrosine (Jassby, 1983).

\section{Acute Toxicity Study And Gross Behaviour In Rats}

Acute toxicity study - up and down procedure - was carried out as per the guidelines set by Organization for Economic Co-operation and Development (OECD).

If animal dies at particular dose, lower dose was given to next animal and if animal survives at a particular dose next higher dose was given for remaining animals. The maximum upper limit dose $2000 \mathrm{mg} / \mathrm{kg}$ of $S P$ was administered orally to mice. Animals were observed individually after dosing.

Observation included mortality and clinical signs, such as changes in skin fur, eyes and mucous membranes. The effect of $S P$ on passivity, grip strength, pain response, stereotypy, vocalization, righting reflex, body weight and water intake was assessed (Lipnic et al., 1995). Pilot study was carried out with various doses (50, 100, 200 and 400 $\mathrm{mg} / \mathrm{kg}$, per oral route to rats) of $S P$. At doses of 100,200 and $400 \mathrm{mg} / \mathrm{kg}$, it was active and at $50 \mathrm{mg} / \mathrm{kg}$ it was inactive. Based on this observations three different doses $(100,200$ and $400 \mathrm{mg} / \mathrm{kg})$ of $S P$ were selected in the present studies.

\section{Results}

\section{Forced Swim Test (FST)}

The results (Table. 1) showed that both $S P$ (100, 200 and 400 $\mathrm{mg} / \mathrm{kg}$, p.o.) and imipramine $(15 \mathrm{mg} / \mathrm{kg}$, i.p.) significantly decreased the duration of immobility time in a dose dependent manner in FST model. Post-hoc analysis showed that the $S P(100,200$ and $400 \mathrm{mg} / \mathrm{kg})$ and Imipramine (IMP) treated groups were significantly different $(\mathrm{p}<0.001)$ from the vehicle treated group (Fig. 1). 


\begin{tabular}{|l|l|l|}
\hline $\begin{array}{l}\text { Group } \\
\text { no. }\end{array}$ & $\begin{array}{l}\text { Treatment } \\
\text { (dose in } \mathbf{~ m g} / \mathrm{kg})\end{array}$ & $\begin{array}{l}\text { Immobility period } \\
\text { (sec) } \\
\text { Mean } \pm \text { SEM }\end{array}$ \\
\hline I & Control $(0.3 \% \mathrm{CMC})+$ FST & $149.2 \pm 1.905$ \\
\hline II & Spirulina $(100 \mathrm{mg} / \mathrm{kg}$, p.o. $)+$ FST & $120.8 \pm 3.781^{\mathrm{a}}$ \\
\hline III & Spirulina $(200 \mathrm{mg} / \mathrm{kg}$, p.o. $)+$ FST & $88.67 \pm 1.647^{\text {a }}$ \\
\hline IV & Spirulina $(400 \mathrm{mg} / \mathrm{kg}$, p.o. $)+$ FST & $66.67 \pm 1.498^{\mathrm{a}}$ \\
\hline V & Imipramine $(15 \mathrm{mg} / \mathrm{kg}$, i.p. $)+$ FST & $77.67 \pm 1.892^{\mathrm{a}}$ \\
\hline
\end{tabular}

Table. 1. Effect of $S P$ and imipramine (IMP) on forced swim test (FST) in rats.

Each column represents mean \pm S.E.M. of immobility period $(\mathrm{sec}), \mathrm{n}=6 . \mathrm{a}=\mathrm{p}<0.001$ compared to control (One-way ANOVA followed by Student-Newman-Keuls test).

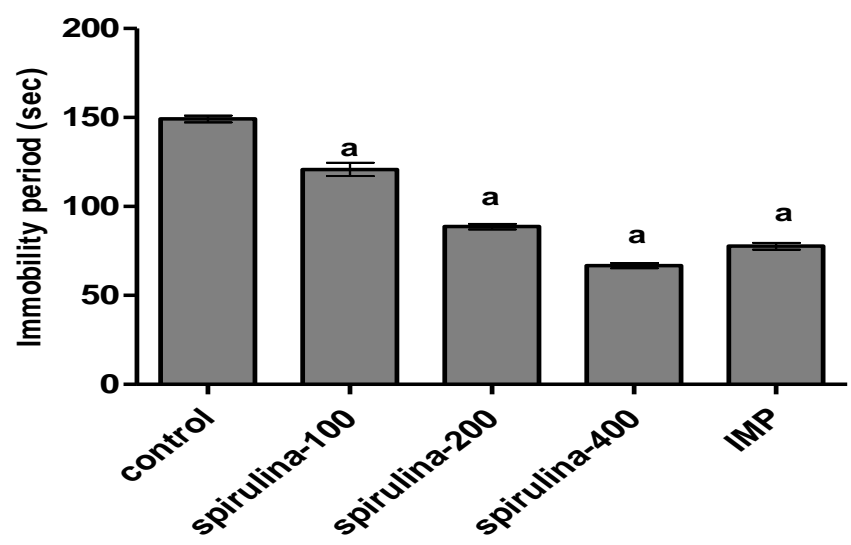

Tail Suspension Test (TST)

The results (Table. 2) showed that both $S P(100,200,400$ $\mathrm{mg} / \mathrm{kg}$, p.o.) and imipramine $(15 \mathrm{mg} / \mathrm{kg}$, i.p.) significantly decreased the duration of immobility time in a dose dependent manner in TST model. Post-hoc analysis showed that the SP (100, 200 and 400 $\mathrm{mg} / \mathrm{kg})$ and IMP treated groups were significantly different $(\mathrm{p}<0.001)$ from the vehicle treated group (Fig. 2).

\begin{tabular}{|l|l|l|}
\hline $\begin{array}{l}\text { Group } \\
\text { no. }\end{array}$ & $\begin{array}{l}\text { Treatment } \\
\text { (dose in } \mathrm{mg} / \mathrm{kg})\end{array}$ & $\begin{array}{l}\text { Immobility period } \\
\text { (sec) } \\
\text { Mean } \pm \text { SEM }\end{array}$ \\
\hline I & Control $(0.3 \% \mathrm{CMC})+$ TST & $148.5 \pm 4.372$ \\
\hline II & Spirulina $(100 \mathrm{mg} / \mathrm{kg}$, p.o. $)+$ TST & $113.5 \pm 4.303^{\mathrm{a}}$ \\
\hline III & Spirulina $(200 \mathrm{mg} / \mathrm{kg}$, p.o. $)+$ TST & $92.5 \pm 2.63^{\text {a }}$ \\
\hline IV & Spirulina $(400 \mathrm{mg} / \mathrm{kg}$, p.o. $)+$ TST & $81 \pm 3.011^{\text {a }}$ \\
\hline V & Imipramine $(15 \mathrm{mg} / \mathrm{kg}$, i.p. $)+$ TST & $72.5 \pm 2.754^{\text {a }}$ \\
\hline
\end{tabular}

Table. 2. Effect of $S P$ and Imipramine (IMP) on tail suspension test (TST) in mice.

Each column represents mean \pm S.E.M. of immobility period $(\mathrm{sec}), \mathrm{n}=6 . \mathrm{a}=\mathrm{p}<0.001$ compared to control (One-way ANOVA followed by Student-Newman-Keuls test).

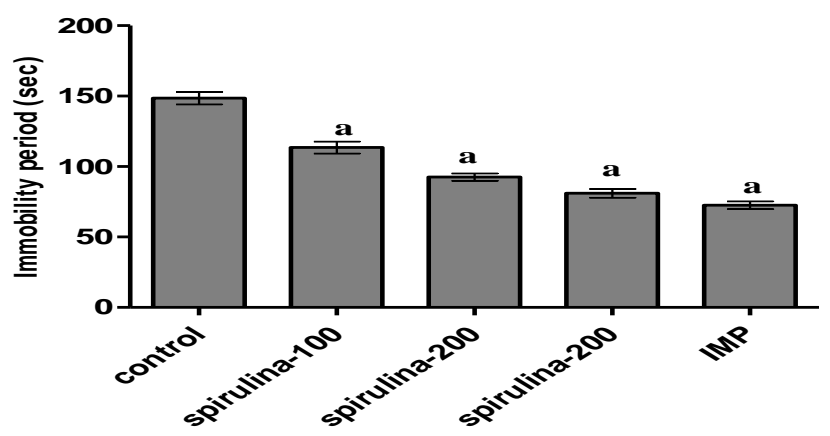

\section{5-HTP induced head twitches in mice}

Table.3. illustrates the effect of SP and IMP on 5-HTP-induced head twitches in mice. Post-hoc analysis revealed that three doses of $S P$ $(100,200$ and $400 \mathrm{mg} / \mathrm{kg}, \mathrm{p}<0.01, \mathrm{p}<0.001)$ significantly increased the 5HTP-induced head twitches in comparison to control group. Further, the dose of $400 \mathrm{mg} / \mathrm{kg}$ was more effective than $100,200 \mathrm{mg} / \mathrm{kg}$. Similarly, IMP treated group showed significant increase $(\mathrm{p}<0.001)$ in the 5-HTPinduced head twitches compared to control. However, the effect of 400 $\mathrm{mg} / \mathrm{kg}$ of $S P$ was significantly higher than IMP (p<0.001) (Fig. 3).

\begin{tabular}{|l|l|l|}
\hline $\begin{array}{l}\text { Group } \\
\text { no. }\end{array}$ & $\begin{array}{l}\text { Treatment } \\
\text { (dose in } \mathbf{~ m g} / \mathrm{kg})\end{array}$ & $\begin{array}{l}\text { Head twitches } \\
\text { Mean } \pm \text { SEM }\end{array}$ \\
\hline I & Control $(0.3 \% \mathrm{CMC})$ & $13.67 \pm 0.8028$ \\
\hline II & Spirulina $(100 \mathrm{mg} / \mathrm{kg}$, p.o. $)$ & $19.83 \pm 1.078^{\mathrm{a}}$ \\
\hline III & Spirulina $(200 \mathrm{mg} / \mathrm{kg}$, p.o. $)$ & $24 \pm 1.366^{\mathrm{b}}$ \\
\hline IV & Spirulina $(400 \mathrm{mg} / \mathrm{kg}$, p.o. $)$ & $31.5 \pm 1.335^{\mathrm{b}}$ \\
\hline V & Imipramine $(15 \mathrm{mg} / \mathrm{kg}$, i.p. $)$ & $21.5 \pm 1.258^{\mathrm{b}}$ \\
\hline
\end{tabular}

Table. 3. Effect of SP on 5-HTP-induced head twitches in mice.

Each column represents mean \pm S.E.M. of number of head twitches, $\mathrm{n}=6 . \mathrm{a}=\mathrm{p}<0.01, \mathrm{~b}=\mathrm{p}<0.001$ compared to control (One-way ANOVA followed by Student-Newman-Keuls test).

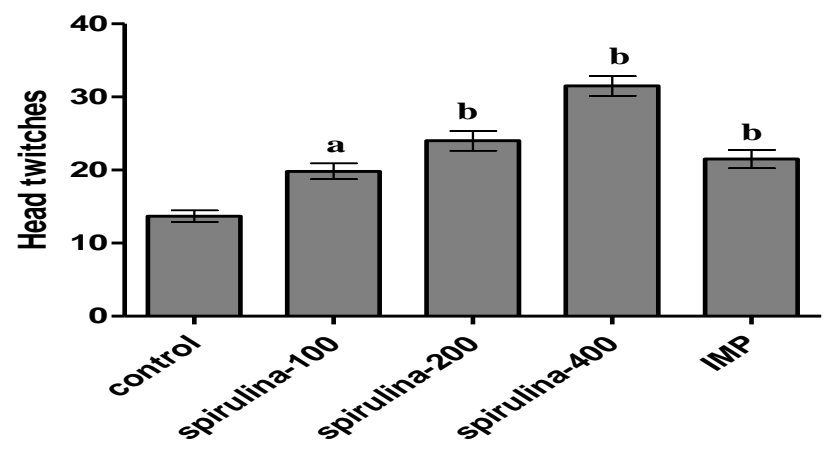

\section{Conclusion}

- The results from the present study confirm the antidepressant activity ofSpirulina platensis, since it reduced the immobility in both FST and TST.

- In the present study, SP significantly increased the frequency of 5HTP induced head twitches, Clonidine induced aggression and LDOPA induced hyperactivity and aggressive behavior indicating its enhanced activity on serotonergic, noradrenergic and dopaminergic pathways respectively. Our results also confirm the involvement of serotonergic, noradrenergic and dopaminergic pathways in depression.

- $\quad$ Pretreatment with SPalso significantly increased the levels of SOD and Catalase with simultaneous decrease in LPO levels in rat brain, suggesting its strong antioxidant activity. Since oxidative stress is reported to play an important role in depression, the antioxidant activity of $S P$ might be a part of the mechanism for its antidepressant activity. 
Results from behavioral experiments indicate that the antidepressant activity of Spirulin platensis might be due to the facilitatory effect on serotonergic, noradrenergic and dopaminergic systems apart from the antioxidant activity.

\section{References}

1. Abdulqader, G., Barsanti, L., Tredici, M. "Harvest of Arthrospira platensis from Lake Kossorom (Chad) and its household usage among the Kanembu." Journal of Applied Phychology. 2000; 12: 493-498.

2. Adell A, Castro E, Celada P, Bortolozzi A, Pazos A, Artigas F. Strategies for producing faster acting antidepressants. Drug Discov Today 2005; 10: 578-85.

3. Anderson IM. SSRIs versus tricyclic antidepressants in depressed inpatients: a metaanalysis of efficacy and tolerability. Depress Anxiety 1998; 7:11-7.

4. Anguelova M, Benkelfat C, Turecki G. A systematic review of association studies investigating genes coding for serotonin receptors and the serotonin transporter: I. Affective disorders. Mol Psychiatry 2003a; 8:574-91.

5. Arutla, S., Arra, G. S., Prabhakar, C. M., Krishna, D.R. "ProAnd Anti-Oxidant Effects Of Some Antileprotic Drugs in Vitro And Their influence On Super Oxide Dismutase Activity" Arzneim.-ForschJDrug Res. 1998; 48: 1024.

6. Aychunie S., et al. "Inhibition of HIV-1 replication by an aqueous extract of Spirulina platensis (Arthospira platensis)." International Association of Applied Algology, 7th International Conference. 16 April 1996, Knysna, South Africa.

7. Ayehunie, S., Belay, A., Baba, T.W., and Ruprecht, R.M. "Inhibition of HIV1 replication by an aqueous extract of Spirulina platensis (Arthrospira platensis)." J Acquir Immune Defic. Syndr. Hum. Retroviro, 1998; 18(1):7-12.

8. Baker GB, Dewhurst WG. Biochemical theories of affective disorders. In: Dewhurst W G, Baker G B (eds) Pharmacotherapy of affective disorders. Croom Helm, Beckenham; 1985.

9. Beers RF, Sizer IW. A spectrophotometric method for measuring the breakdown of hydrogen peroxide by catalase. $\mathrm{J}$ Biol Chem 1952; 195:133-40.
10. Belay A. \& Ota Y. "Current knowledge on potential health benefits of Spirulina" Journal of Applied Physiology, 1993; 5:235241.

11. Belay A. The potential application of Spirulina (Arthrospora) as a nutritional and therapeutic supplement in health management. JANA 2002; 5:27-48

12. Bhattacharya SK, Bhattacharya A, Sairam K, Ghosal S. Anxiolytic-antidepressant activity of Withania somnifera glycowithanolides: an experimental study. Phytomedicine 2000; 7:463-9.

13. Bilici M, Efe H, Koroglu MA, Uydu HA, Bekaroglu M, Deger O. Antioxidative enzyme activities and lipid peroxidation in major depression: alterations by antidepressant treatments. J Affective Disorders 2001; 64:43-51.

14. Blier P, De Montigny C. Current advances and trends in the treatment of depression. Trends Pharmacol Sci 1994; 15:220-6.

15. Blier P. The pharmacology of putative early-onset antidepressant strategies. Eur Neuropsychopharmacol 2003; 13:57-66.

16. Blinkova, L.P., Gorobets, O.B., and Baturo, A.P. "Biological activity of Spirulina." Zh Mikrobiol Epidemiol Immunobiol, 2001; (2):114-8.

17. Borsini, F., Meli, A. Is the forced swimming test a suitable model for revealing antidepressant activity? Psychopharmacology (Berl). 1988; 94 (2):147-160.

18. Bujard E, Braco U, Mauron J, Mottu F, Nabholz A, Wuhrmann JJ \& Clément G , "Composition and Nutritive Value of Blue Green Algae (Spirulina) and their Possible Use in Food Formulations." 3rd. International Congress of Food Science and Technology, Washington, 1970.

19. Butterweck, V., Christoffel, V., Nahrstedt, A., Petereit, F., Spengler, B., Winterhoff, H. Step by step removal of hyperforin and hypericin: activity profile of different hypericum preparations in behavioral models. Life Sci 2003; 73, 627-639.

20. Challem JJ, Passwater RA, \& Mindell EM, "Spirulina" Keats Publishing, Inc. New Canaan, Connecticut, 1981. 